because of coincident age related neurogenic changes in these muscles. ${ }^{18}$

These newly recognised features of incontinence have practical implications: thus treatment by electronic devices intended to stimulate sphincter muscles is unlikely to be effective if there is pronounced muscle denervation, nor will drugs to promote contraction of denervated muscles be of any use. Surgical treatment of urinary or faecal incontinence should offer more help, and one of its objectives should be to reconstruct the pelvic floor muscle plane, as, for example, in the operation of postanal repair for anorectal incontinence devised by Parks. ${ }^{4}$ Finally, there is a place for preventive action, by attending to the factors that underlie damage to the innervation of the pelvic floor during childbirth, ${ }^{15}$ and to the deranged defecatory pattern in patients with constipation, perineal descent, and straining at stool. Such measures should reduce the frequency of this distressing disability.

M SWASH

Consultant Neurologist,

The London Hospital and St Mark's Hospital,

London

Thomas TM, Plymat KR, Blannin J, Meade TW. Prevalence of urinary incontinence. Br Med $\mathcal{J}$ 1980;281:1243-5.

2 Leigh RJ, Turnberg LA. Faecal incontinence: the unvoiced symptom. Lancet 1982;i:1349-51.

3 Hald T, Bradley WE. The Urinary bladder: neurology and dynamics. Baltimore, London: Williams and Wilkins, 1982

Parks AG. Anorectal incontinence. Proceedings of the Royal Society of Medicine 1975;68:681-90.

Henry MM, Parks AG, Swash $M$. The pelvic floor musculature in the descending perineum syndrome. Brf Surg 1982;69:470-2.

6 Neill ME, Parks AG, Swash $M$. Physiological studies of the anal sphincter musculature in faecal incontinence and rectal prolapse. Br $\mathcal{I}$ Surg 1981;68:531-6.

AG, Swash $M$, Urich $H$. Sphincter denervation in anorectal incontinence and rectal prolapse. Gut 1977;18:656-65.

. Pathogenesis of rectal incontinence: a histometric study of the anal sphincter musculature. I Neurol Sci 1979:42:111-27.

Bartolo DCC, Jarratt JA, Read NW. The use of conventional electromyography to assess external sphincter neuropathy in man. I Neurol Neurosurg Psychiatry 1983;46:1115-8.
sper

sphincter neuropathy in man. F Neurol Neurosurg Psychiatry 1983;46:1115-8.
$10 \mathrm{Neill} M \mathrm{ME}$, Swash $\mathrm{M}$. Increased motor unit fibre density in the external anal sphincter muscle in anorectal incontinence: a single fibre EMG study. $\mathcal{F}$ Neurol Neurosurg Psychiatry 1980;43:343-7.

Snooks SJ, Barnes PRH, Swash M. Damage to the voluntary anal and urinary sphincter muscu

lature in incontinence. $\mathcal{F}$ Neurol Neurosurg Psychiatry (in press).

$\mathrm{Kiff} \mathrm{E}$, Swash $\mathrm{M}$. Slowed conduction in the pudendal nerves in idiopathic (neurogenic) faecal incontinence. Br F Surg 1984;71:614-6.

Brindley GS. Electro-ejaculation: its technique, neurological implications and uses. 7 Neurol Neurosurg Psychiatry 1981;44:9-18

rey JP, Neill ME, Swash M, Parks AG. Electrophysiological study of the motor nerve supply of the pelvic floor. Lancet $1981 ; 1: 16-7$.

nooks $S J$, Setchell $M$, Swash $M$, Henry MM. Injury to the innervation of the pelvic floor the 1984 ;ii.546-50.

nooks SJ, Swash M. Abnormalities of the innervation of the urethral striated sphincter musculature in incontinence. $\mathrm{Br}$ J Urol 1984;56:401-5.

Anderson RS. A ne $1984 ; 91: 412-45$.
.

Percy JP, Neill ME, Kandrah TK, Swash M. A neurogenic factor in faecal incontinence in the elderly. Age Ageing 1982;11:175-9.

\section{The world cancer burden: prevent or perish}

The industrialised Western countries do not have a monopoly of cancer. Recently the International Agency for Research on Cancer and the cancer unit at the World Health Organisation in Geneva examined data on incidence, mortality, and relative frequency to derive estimates of the number of new cases of cancer in the 24 areas of the world for which the United Nations publishes population data.' International cancer statistics take time to appear so that 1975 was used as the reference year; the estimate, probably rather conservative, of the annual number of new cases of cancer was 5.9 million. The six most frequent cancers in men were of lung (464 000), stomach (422 000), colon and rectum (251000), mouth and pharynx (233 000), prostate (198 000), and oesophagus (194000); in women they were of breast (541 000), cervix uteri (459 000), stomach (261 000), colon and rectum (256 000), lung (127000), and mouth and pharynx $(107000)$. These cancers, together with those of liver, bladder, lymphatic tissues, and leukaemia accounted for three quarters of all new malignancies. Combining the sexes, stomach cancer was first in rank order closely followed by lung. These figures represent a desert of human misery and of premature death.

The striking variations from nation to nation in the patterns of occurrence of cancer have been interpreted as reflecting differences in exposure to environmental risk factors. Genetic variation can account for only a small proportion of these differences- the changes over time in the incidence of many cancers are too rapid to be explained in this way. Even more compelling is the evidence from migrant studies showing that people who move to another country are found to have the pattern of cancers of their new home within one or two generations. ${ }^{2-4}$ Such population comparisons and evidence from experimental and epidemiological studies strongly suggest that as much as $80-90 \%$ of human cancer is determined environmentally and thus theoretically avoidable. ${ }^{5.7}$ The term environment embraces all elements of lifestyle-dietary, social, and cultural habits (in which the specific carcinogenic factors may be ill understood)-as well as exposure to carcinogens at work, radiation, drugs, and so on. Once specific causes have been identified rational prevention should be possible and the resources now devoted to treatment more profitably used. What, then, are the possibilities for prevention?

Tobacco is the most important single aetiological factor in cancer; in the United States, for example, where cigarette smoking is common, around $30 \%$ of all deaths from cancer may be attributed to the habit. ${ }^{8}$ Two thirds of the new cases of lung cancer in 1975 occurred in developed countries where smoking is very prevalent ${ }^{1}-$ and at least $80 \%$ are avoidable. Even if a smaller fraction of lung cancers in other countries are induced by tobacco $60-75 \%$ of the global total must surely be attributable to this single cause. Cancers of the mouth and pharynx are due to chewing betel quid, with and without tobacco, in middle south Asia (where over a third of the incident cases originate) and to the combination of tobacco and alcohol in some Western countries. The risk of many other cancers-of larynx, oesophagus, bladder, and pancieas -is increased by cigarette smoking, ${ }^{8}$ so that as much as $15 \%$ of the global cancer burden, or around 900000 new cases a year, can be attributed to this single agent. If tobacco consumption in the developing world continues to grow (which vigorous promotional campaigns are seeking to encourage) then this proportion must increase. ${ }^{9}$

In 1975 stomach cancer was the most commonly occurring tumour, but its incidence is declining everywhere. The cause of this fall is not fully understood, but it may be related to methods of storing foodstuffs, and there is some evidence for a protective effect of a diet rich in fresh fruit and vegetables (and low in salted food).

Many other studies, epidemiological and experimental, point to the importance of diet in carcinogenesis and its inhibition..$^{10-12}$ Most of the dietary customs implicated in increasing the risk of cancer-overnutrition, excess intake of fat and meat, deficit of fibre-are characteristic of the so called "Western diet." Over half of the cancers of the breast (541000 cases yearly), two thirds of colorectal cancer (507 000), and three quarters of prostate cancer (198 000) tumours which have been linked to such diets-occur in the developed nations. Societies do change and can be persuaded to change their dietary patterns (though agricultural and food processing interests may be somewhat resistant)-but as yet we do not know enough confidently to prescribe a risk reducing diet other than in the most general terms: eat less; 
increase fibre, fruit, and vegetables; and reduce fat. Persuading people to eat more fibre may be relatively easy, but persuading them to give up animal fat seems likely to be much more difficult.

For most of mankind, however, overnutrition does not present a problem; their risks stem from dietary deficiencies, possibly of micronutrients such as vitamin A and its precursors, ${ }^{13}$ and from specific carcinogens-for example, mycotoxins. ${ }^{14}$ Trials are currently under way to assess the effects of vitamin supplementation on the incidence of cancer ${ }^{15}$ and the progression of preinvasive lesions. ${ }^{16}$

The overall incidence of cancer of the cervix is slightly less than that of cancer of the breast, but in the developing nations cervical cancer predominates in the ratio of $3: 2$. A recent decline in incidence in several Western countries appears to be the result of low risk generations of women (born between the wars) being subjected to population screening programmes. Such a relatively expensive intervention is less suitable for developing countries, but until more is known of the (possibly infectious) aetiology of this cancer primary prevention is not feasible.

One globally important cancer, that of the liver, has been shown to have an infectious cause, the excess risk among carriers of the hepatitis B virus being at least 100 -fold.$^{17}$ If (as seems likely) vaccination reduces carriers by $90 \%$, and if neonates in Africa, South East Asia, and China could be vaccinated, then nearly 200000 cases of cancer (about $3 \%$ of the total) would be avoided each year.

As populations both increase and age these two effects will result in ever growing numbers of cancers needing to be diagnosed and treated. We conservatively estimate that, with present knowledge, it would be possible to reduce the toll by one quarter or 1.5 million cases a year. To promise substantial reduction after 10 years (if we assume a major role for promoters) is somehow not as appealing as that elusive will o' the wisp-the cure for cancer. Yet Thomas Adams said it all, over 300 years ago: "Hee is a better physician that keepes diseases off us, than hee that cures them being on us. Prevention is so much better than healing, because it saves the labour of being sick."

C S MUIR

Chief, unit of descriptive epidemiology, division of epidemiology and biostatistics

D M PARKIN

Medical officer

International Agency for Research on Cancer,

150 Cours Albert Thomas,

69372 Lyon Cedex 08,

France

Parkin DM, Stjernsward J, Muir CS. Estimates of the worldwide frequency of twelve major

$2 \mathrm{Kmet} J$. The role of migrant populations in studies of selected cancer. $\mathrm{F}$ Chronic Dis 1970;23:305 24.

United States Public Health Service. Populations at low risk of cancer; cancer patterns in ethnic groups. JNCI 1980;65:1127-59.

Marmot MG, Adelstein AM, Bulusu L. Immigrant mortality in England and Wales 1970-78 Causes of death by country of birth. London: HMSO, 1984. Studies on Medical and Population Subjects, No 47

Wynder EL, Gori GB. Contribution of the environment to cancer incidence: an epidemiologic exercise. INCI 1977;58:825-32.

Higginson J, Muir CS. Environmental carcinogenesis: misconceptions and limitations to cancer control. FNCI 1979;63:1291-8.

7 Doll R, Peto R. The causes of cancer. Oxford: Oxford University Press, 1981. nited States Public Health Service. The health consequences of smoking: cancer. A report of the Surgeon General. United States Department of Health and Human Services, Office on Smoking and World Health Organisation. Controlling the smoking epidemic. Geneva: World Health Organisation, 1979. (Technical Report Series, 636.)

10 Graham S. Towards a dietary prevention of cancer. Epidemiol Rev 1983;5:38-50

1 Willett WC, MacMahon B. Diet and cancer-an overview. N Engl f Med 1984;310:633-8

2 Willett WC, MacMahon B. Diet and cancer-an overview. N Englf Med 1984;310:697-703.

3 Peto $\mathrm{R}$, Doll $\mathrm{R}$, Buckley JD, Sporn $\mathrm{MD}$. Can dietary beta-carotene materially reduce human cancer rates? Nature 1981;290:201-8.

International Agency for Research on Cancer. Monographs on the evaluation of carcinogenic risk to humans. Aftatoxin. Some naturally occurring substances. Vol 10. Lyons: International Agency
for Research on Cancer, 1976:51-72. for Research on Cancer, 1976:51-72.

Prev 1984:7:147-58.
. Prev $1984,7.147-58$.

for Research on Cancer, 1984:51-6.
17 Beasley RP, Hwang LY, Lin CC, Chien CS. Hepatocellular carcinoma and hepatitis B virus. A prospective study of 22707 men in Taiwan. Lancel 1981;ii:1129-33.

18 Adams T. Works. The Happinesse of the Church. Quoted by Strauss. ${ }^{19}$

\section{Festschrift for Sir Francis Avery Jones}

In 1934 Francis Avery Jones became house physician at St Bartholomew's Hospital to Leslie Witts, who was investigating the value of the Meulengracht diet in patients with gastrointestinal bleeding. He noted that many patients who died were severely uraemic, an observation that eventually led to his advocacy of early feeding and adequate replacement of fluid and electrolytes-revolutionising the treatment of these patients. As Alan Read remarks in the recent tribute to Avery's 50 years of medical practice, "present day clinical management . . . has progressed very little since his contributions." When he was appointed physician to the Central Middlesex Hospital in 1940 he began a systematic study of the causes and outcome of haematemesis and melaena, and by the time he retired from hospital practice in 1973 he had investigated and treated some 5000 patients.

His was the first specialist unit in a district general hospital in Britain, and its interests embraced the whole range of gastroenterology. Its reputation was such that it received considerable support from the Nuffield Foundation and the Medical Research Council and attracted more than 200 research fellows from overseas. Many of today's household names in medicine and gastroenterology, as is evident in the festschrift, began their careers with Avery. One of these was Sir Richard Doll, who describes the beginning of controlled clinical trials in Britain and lists no fewer than 30 papers describing trials carried out at the Central Middlesex and St Mark's Hospitals. This early enthusiasm exemplifies one of Avery's two guiding principles-namely, that treatment should be scientifically based. The other-early and accurate diagnosis-is witnessed by his advocacy of gastrointestinal endoscopy: gastroenterologists should carry a sigmoidoscope in their pockets like a pen, he maintained. Basil Hirschowitz, who was working with the physicist $\mathrm{H} \mathrm{H}$ Hopkins on fibreoptic transmission, designed a prototype gastroscope while with Avery (was it actually used?) but sadly had to take it to the United States for development. As a result he has not received due recognition in this country for one of the major advances in gastroenterology.

Clinician, scientist, and teacher, with what Lennard Jones describes as "an unerring instinct for progress," Avery has also been a passionate supporter of Britain's health care system. As a member of the King's Fund for 35 years he has been concerned with projects as varied as hospital catering, the Emergency Bed Service, design of the hospital bed, and medical records. "He preferred to work behind the scenes," writes Ian McColl of these projects, "putting forward ideas and content if others took them up and made them their own." But his radical views are as apparent here as in his clinical practice. The success story of British gastroenterology in the past 50 years is in large measure a tribute to the work of Sir Francis Avery Jones and those he inspired.

1 Festschrift for Sir Francis Avery Jones. Fifty years of medical practice 1934-1984. Postgrad Med $\mathcal{J}$ 1984;60:715-831. 